\title{
O MOVIMENTO DOS TRABALHADORES RURAIS SEM-TERRA (MST) E A DEMOCRACIA NO BRASIL ${ }^{1}$

\author{
THE MOVEMENT OF LANDLESS RURAL WORKERS' (MST) AND \\ DEMOCRACY IN BRAZIL
}

\author{
Dr. Miguel Carter ${ }^{2}$ \\ carter@american.edu
}

Resumo: Este trabalho examina as relações do Movimento dos Trabalhadores Rurais Sem Terra (MST) com a democracia no Brasil. O MST é a principal organização popular da América Latina e um dos mais importantes movimentos sociais pela reforma agrária na história mundial. Contrariando certas opiniões influentes, este ensaio argumenta que o MST não é uma organização "anti-Estado" ou "anti-democrática". As ações do MST junto às instituições políticas do Brasil são multifacetadas e dinâmicas. Estas incluem o ativismo público e atos de desobediência civil, lobby e negociações, corporativismo social ad hoc, participação eleitoral e relações diversas com o Estado de Direito. Dada a crua realidade da luta agrária no Brasil -- e as opções reais disponíveis ao MST - a conduta de resistência e pressão política deve ser compreendida, em primeiro lugar, como sustentada em considerações práticas mais do que em qualquer ideologia dogmática. O perfil contencioso do MST tem sido necessário para avançar a reforma agrária no Brasil e melhorar a qualidade da sua democracia, no sentido de: (1) fortalecer a sociedade civil através da organização e incorporação de setores marginalizados da população; (2) realçar a importância do ativismo público como catalisador do desenvolvimento social; (3) facilitar a extensão e exercício de direitos básicos de cidadania entre os pobres; e, (4) gerar um sentido de utopia e afirmação de ideais que impregnam o processo de

\footnotetext{
${ }^{1}$ Trabalho originalmente publicado em Maio de 2005: "The Landless Workers Movement (MST) and Democracy in Brazil.", Centre for Brazilian Studies Working Paper CBS-60-05, University of Oxford. O autor gostaria de agradecer os comentários às versões preliminares deste texto de Leslie Bethell, Kristina Svensson, Patrick Quirk, Esteban Quiñones e Marta Inez Medeiros Marques.

2 Assistant Professor, School of International Service, American University,Washington, DC e Associate Researcher, Centre for Brazilian Studies,University of Oxford, Oxford, United Kingdom.
} 
democratização do Brasil no seu longo prazo, complexidade e conseqüências abertas. Por virtude de nascimento e necessidade, a marca distintiva do MST junto à democracia brasileira tem sido a do "jogo duro".

\begin{abstract}
This paper reviews the Movement of Landless Rural Workers' (MST) relations with democracy in Brazil. The MST is Latin America's premier grassroots organization and one of the most significant social movements for land reform in world history. Contrary to influential views, this essay argues that the MST is not an "anti-state" or "anti-democratic" organization. MST engagements with Brazil's political institutions are multifarious and dynamic. These include public activism and acts of civil disobedience, lobbying and bargaining, ad hoc societal corporatism, electoral participation, and manifold relations with the rule of law. Given the crude realities of Brazil's agrarian struggle - and the actual options available to the MST - the movement's oppositional demeanor and pressure politics must be understood, first and foremost, as grounded on practical considerations rather than any dogmatic ideology. The MST's contentious edge has been necessary to advance Brazil's agrarian reform and improve the quality of its democracy by: (1) strengthening civil society through the organization and incorporation of marginalized sectors of the population; (2) highlighting the importance of public activism as a catalyst for social development; (3) facilitating the extension and exercise of basic citizenship rights among Brazil's poor; and, (4) engendering a sense of utopia and affirmation of ideals imbued in Brazil's long term, complex and open-ended democratization process by virtue of birth and necessity, the MST's distinct mark on Brazilian democracy has been that of the "tough touch."
\end{abstract}




\section{Sem luta não há progresso.}

Aqueles que professam em favor da liberdade, e ainda depreciam a agitação, são pessoas que querem ceifar sem arar a terra. Eles querem chuva sem trovão e raios.

Eles querem o oceano sem o terrivel bramido de suas muitas águas.

Esta luta pode ser moral; ou pode ser física; ou pode ser ambas, moral e física; mas ela deve ser uma luta. O poder não concede nada sem demanda.

\section{Nunca concedeu e nunca concederá.}

\section{Frederick Douglass ${ }^{3}$}

Na noite de 29 de outubro de 1985, mais de 200 caminhões, ônibus e carros saíram de 32 municípios do estado do Rio Grande do Sul para ocupar uma fazenda de gado de 9.200 hectares, na sua maior parte inativa, conhecida como Fazenda Annoni. Mais de 6.000 pessoas participaram no que até então era a maior e mais bem planejada ocupação de terras na história do Brasil. Pela manhã eles tinham levantado uma extensa vila de tendas negras e organizado uma equipe de segurança para evitar despejo por parte da polícia. Em uma questão de dias, os camponeses estabeleceram uma elaborada organização interna: uma rede de grupos de famílias, uma variedade de equipes de trabalho, uma coordenação central e um conselho de direção. A vida diária no acampamento era cheia de atividades e reuniões. Próximos a uma área de floresta densa, os sem-terra reuniam-se diariamente para uma grande cruzada de orações, canções religiosas e de protesto, anúncios e palavras entusiastas de encorajamento de muitos apoiadores. Uma vasta rede de solidariedade foi estabelecida para promover a causa dos camponeses na Fazenda Annoni. Pouco depois da ocupação, o Bispo da região e oitenta padres compareceram ao acampamento para abençoar a luta dos sem-terra.

Aproximadamente 1.250 famílias obtiveram a propriedade das terras por meio da pressão conjunta e a prolongada mobilização que se seguiu à ocupação da Fazenda Annoni. Isto envolveu um amplo conjunto de medidas e ações coletivas

\footnotetext{
${ }^{3}$ Carta escrita por Frederick Douglass para um associado abolicionista, em 1848, veja Bobo, Kendall, e Max (1996).
} 
essencialmente não-violentas. As mesmas incluíram entre incontáveis esforços para conquistar o apoio de representantes do governo, incluindo três viagens para reunir com autoridades nacionais em Brasília, e uma série de sofisticadas táticas de protesto. As estatísticas básicas da luta empreendida pelos ocupantes da Fazenda Annoni são reveladoras. Nos oito anos que levou para assentar todas estas famílias, os sem-terra da Fazenda Annoni engajaram-se em: 36 ocupações de terra; ao menos 30 grandes comícios de protesto; nove greves de fome; duas longas marchas, incluindo uma macha, de $450 \mathrm{~km}$ e 27 dias, a Porto Alegre, capital do estado; três bloqueios de estradas e nove ocupações de edifícios, seis delas no Instituto Nacional de Colonização e Reforma Agrária (INCRA) e três ocupações na Assembléia do Estado. Dez vidas humanas foram perdidas nesses conflitos, incluindo sete crianças, as quais morreram devido a condições precárias de saúde no acampamento dos sem-terra. Dos três adultos, dois eram sem-terra e um era um oficial da polícia morto durante um conflito em Porto Alegre. Gradualmente, o fragmentado e disperso assentamento de todas as famílias da Fazenda Annoni foi finalizado somente em $1993 .{ }^{4}$

Aqui se ergue um momento de construção e uma sinopse ilustrativa de um dos mais importantes movimentos sociais de reforma agrária na história mundial: o Movimento dos Trabalhadores Rurais Sem Terra do Brasil, mais conhecido pelas suas iniciais MST. Por todos os relatos, o MST, hoje, é o principal movimento popular da América Latina e uma das mais notáveis organizações camponesas do mundo.

Este artigo tem por objetivo tratar de duas questões básicas: Como o MST se relaciona com processo político do Brasil? E qual a contribuição do MST para a democracia no Brasil? Estas perguntas, todavia, demandam uma pergunta inicial: o que é o MST? Por esta razão, este estudo começa oferecendo uma breve descrição do MST - o contexto histórico no qual ele surge, sua evolução e fontes de poder. As duas seções seguintes examinam os mais variados meios pelos quais o MST se relaciona com o

\footnotetext{
4 Estas estatísticas provêm de uma extensa base de dados que construí sobre as, "Mobilizações de Terras no Rio Grande do Sul, 1978-2003." Informações desta base de dados foram compiladas das mais variadas fontes, principalmente arquivos históricos encontrados nos escritórios da Comissão Pastoral da Terra (CPT) em Goiânia e Porto Alegre. Outros documentos consultados incluem INCRARS (2003); MST-RS (2003); várias tiragens do Jornal dos Sem Terra do MST; e várias tiragens do Voz da Terra da CPT do Rio Grande do Sul. Entre 1991 e 2003 eu realizei entrevistas com mais de 250 ativistas da reforma agrária, cientistas sociais, autoridades eclesiásticas e relevantes oficiais do governo no Rio Grande do Sul. Eu sou grato particularmente a Luiz Antonio Pasinato do escritório do CPT em Porto Alegre por sua assistência na obtenção de valiosas estatísticas.
} 
processo político brasileiro. Fazendo isso, eu critico uma avaliação recorrente e partilhada por proeminentes analistas deste movimento social.

Influentes intelectuais brasileiros como José de Souza Martins, Zander Navarro e Francisco Graziano afirmam que as relações de confrontação do MST com as instituições do governo brasileiro são prejudiciais para a democracia. Para Martins, professor emérito da Universidade de São Paulo e um dos sociólogos rurais mais renomados do Brasil, o MST é o equivalente local para o Movimento Luddita inglês, uma breve revolta popular nos primórdios do século XIX, célebre por danificar as novas máquinas das fábricas. Incitado por crenças fundamentalistas similares, o MST "recusa reconhecer a legitimidade institucional e ações do governo e do estado". De fato, de acordo com Martins, as ações do movimento e suas demandas representam uma "tentativa pré-política e precária de demolir a ordem política". Navarro, professor de sociologia da Universidade Federal do Rio Grande do Sul, descreve o MST como uma organização "anti-sistêmica" e "anti-Estado", guiada por uma rígida disposição marxista a se engajar em ações não-institucionais. Graziano, um ex-deputado federal (PSDB-São Paulo) que foi por pouco tempo presidente do INCRA sob o governo do Presidente Fernando Henrique Cardoso, descreve o MST como "uma organização guerrilheira autoritária" que está "minando a democracia" com suas ocupações de terra, e igualmente encorajando ações de "terrorismo" no campo. Todos os três proeminentes analistas afirmam que o MST é essencialmente um movimento "antidemocrático". 5

Neste texto eu demonstro que este suposto conflito ente o MST e as instituições democráticas brasileiras é muito mais retórico do que real. O MST não é uma organização "anti-Estado". Totalmente ao contrário, ele demanda que o Estado desempenhe um papel mais ativo no desenvolvimento social. Além disso, o movimento é continuamente engajado em persuadir e barganhar com diferentes escalões do Estado, e tem se envolvido em numerosos projetos em colaboração com autoridades públicas. $\mathrm{O}$ aguçado ímpeto do MST é condicionado notavelmente pela espantosa desigualdade de distribuição de terras do Brasil, a difundida pobreza rural, a falta de oportunidade de

5 As citações são de Martins (2002: 18-19, 26); Navarro (2002a:208, 211; 2002b: 279); Graziano (2004: 304, 72). Veja também Martins (2003). As idéias abraçadas pelos três analistas têm recebido ampla atenção dos principais setores da mídia brasileira. Martins e Navarro são ex-consultores do MST e da Comissão Pastoral da Terra (CPT). Graziano atualmente dirige uma consultoria em agronegócio. 
empregos e a contínua violação dos direitos humanos na zona rural. Dada a natureza desta luta agrária - e as reais opções disponíveis para o MST - a orientação contestatória e política de pressão do movimento devem ser entendidas, antes de tudo, como baseadas em considerações práticas em vez de qualquer ideologia dogmática.

Finalmente, eu sustento que o perfil contencioso do MST tem sido necessário para avançar a reforma agrária e melhorar a qualidade da democracia brasileira. Como eu explico no decorrer deste texto, o MST tem contribuído para a democracia por: (1) fortalecer a sociedade civil brasileira através da organização e incorporação dos setores marginalizados da população; (2) realçar a importância do ativismo público como um catalisador para o desenvolvimento social; (3) facilitar a extensão e exercício dos direitos básicos do cidadão - direitos civis, políticos e sociais entre os pobres; e (4) engendrar um senso de utopia e afirmação de ideais impregnando o longo, complexo e inconclusivo processo de democratização do Brasil. ${ }^{6}$

Um MST cordial e institucionalizado, como Martins, Navarro e Graziano parecem preferir, tornaria o movimento inócuo e frustraria sua razão de ser. À luz da crua realidade da política no meio rural brasileiro e dos poderes tradicionais acumulados por seus grandes proprietários de terras, seria ingênuo, na melhor das hipóteses, esperar que a luta do MST por reforma agrária exija qualquer coisa menos que um "jogo duro".

${ }^{6}$ Esta abordagem sobre democratização é retratada em Laurence Whitehead (2002). 


\section{Entendendo o MST: Contexto, Evolução e Fontes de Poder}

O cenário para a história do MST é o Brasil - o quinto maior país do mundo, em ambos, território e população, a décima economia, e a segunda sociedade mais desigual no globo em termos de distribuição de renda. ${ }^{7}$ Este país também tem um dos maiores índices de concentração de terras do mundo. De acordo com o IBGE, 1\% dos produtores controla $45 \%$ da área de estabelecimentos da nação, enquanto próximo de $37 \%$ dos produtores possuem somente $1 \%$ desta mesma área. ${ }^{8}$ Esta extrema desigualdade da estrutura agrária é conseqüência da história do Brasil. O legado começou com as vastas sesmarias concedidas pela coroa portuguesa como privilégio a destacadas famílias da colônia. Esta desigualdade tem persistido durante os 183 anos que se seguiram à independência de Portugal em 1822; e se reproduzido sob os diferentes regimes - império, república oligárquica, ditadura militar e democracia. ${ }^{9}$

Oficialmente, o MST foi fundado em janeiro de 1984, na cidade de Cascavel, Paraná. Ele surgiu sob a égide da Comissão Pastoral da Terra (CPT), entidade ecumênica auspiciada pela Igreja Católica, como uma coalizão de grupos de camponeses envolvidos em lutas dispersas distribuídas ao longo da metade sul do Brasil. Indubitavelmente, o mais reconhecido de todos estes conflitos teve lugar no Rio Grande do Sul, em 1981, no acampamento de sem terras da Encruzilhada do Natalino, localizado somente a um quilômetro de distância da Fazenda Annoni. A mobilização na Encruzilhada do Natalino é, em muitos sentidos, o equivalente brasileiro para o boicote dos ônibus em Montgomery, Alabama, em 1955-56, liderada pelo Pastor Martin Luther King Jr., o qual levou à formação do movimento pelos direitos civis dos Estados Unidos. $\mathrm{Na}$ verdade, ambos os episódios foram impulsionados pelo vital suporte religioso e serviram para catalisar, em cada país, um movimento nacional de grande expressão. ${ }^{10}$

\footnotetext{
${ }^{7}$ Ver, IPEA (2005).

8 Estes dados são do último censo agropecuário realizado no Brasil, ver IBGE (1996).

9 Para uma revisão histórica de grande utilidade das políticas e estruturas agrárias do Brasil, ver Faoro (1957); Forman (1975); Martins (1997, 1994, 1991, 1990); Guimarães (1989, 1982); Silva (1996); Medeiros (1989); Schmink e Wood (1982); Stédile (1994,1999); Delgado (2005).

${ }_{10}$ Sobre o Movimento da Encruzilhada do Natalino ver Carter (2003, 2005b). Para um relato preciso da greve de ônibus de Montgomery e as origens do movimento pelos direitos civis dos Estados Unidos, ver Branch (1986).
} 
A origem do MST no sul do Brasil foi facilitada pelos níveis relativamente altos de desenvolvimento rural da região, uma presença e capacidade maior do Estado, e índices mais elevados em educação e capital social. O forte legado da produção familiar, particularmente no Rio Grande do Sul, Santa Catarina, e Paraná, uma conseqüência da intensa imigração européia verificada depois de meados do século XIX, ajudaram a nutrir uma ativa e engenhosa sociedade civil. Mais especificamente, a emergência do movimento no sul do Brasil foi estimulada por: (1) anteriores mobilizações de terras no final de 1950 e início de 1960 que estabeleceram um importante precedente histórico; (2) um acelerado impulso em direção à modernização da agricultura, começando na metade de 1960, a qual deixou muitos pequenos produtores fora do mercado de terras; (3) a construção de grandes represas hidrelétricas, começando no início da década de 1970, que deslocou grandes números de famílias camponesas; (4) a intensificação de oportunidades políticas para a mobilização no final da década de 1970, como resultado da abertura gradual do regime militar; e, (5) o progressivo engajamento de agentes religiosos, inspirados pela teologia da libertação e inovações da Igreja Católica introduzidas depois do Concílio Vaticano II (1962-1965). De fato, em lugar algum na história mundial da religião pode se encontrar a principal instituição religiosa de um país desempenhando um papel tão significativo em defesa da reforma agrária quanto a Igreja Católica brasileira. ${ }^{11}$

A partir de uma rede de apoio constituída pela Igreja e por sindicatos rurais, o MST expandiu-se para outras regiões brasileiras e, em meados da década de 1990, estava presente em 23 das 27 unidades federativas do país. Desde este tempo, o MST tem se tornado particularmente ativo na empobrecida região nordeste do Brasil. Atualmente, cerca de 350.000 famílias obtiveram terras através das lutas do MST, em aproximadamente 2.300 assentamentos agrícolas sancionados pelo governo. $\mathrm{O}$ movimento estabeleceu 88 cooperativas e 96 unidades de processamento de alimentos, de

\footnotetext{
11 São importantes fontes sobre a história e evolução do MST Branford e Rocha (2002); Carter (2005a, 2005b); Fernandes (2000); Morissawa (2001); Navarro (1996), Ondetti (2002), Wright e Wolford (2003). Um bom estudo sobre o envolvimento da Igreja no apoio ao MST pode ser encontrado em Poletto (2005); Poletto e Canuto (2002); Adriance (1996); Paiva (1985). Sobre o engajamento progressista da Igreja no Brasil, ver Beozzo (1994); Della Cava (1989) e Mainwaring (1986).
} 
diferentes tamanhos e graus de sucesso. ${ }^{12}$ Nas últimas duas décadas, o MST tem levado o governo brasileiro a distribuir cerca de sete milhões de hectares - um território do tamanho da Irlanda. ${ }^{13}$

Há muitas organizações camponesas engajadas na mobilização pela reforma agrária no Brasil. O MST é predominante no sul, onde ele surgiu. Mas as lutas no Nordeste e na região Amazônica têm sido conduzidas principalmente por sindicatos rurais e vários movimentos localmente organizados, incluindo grupos informais de posseiros. Hoje, cerca de $45 \%$ dos assentamentos rurais no Brasil estão de certo modo conectados com o MST. ${ }^{14}$ Mais de $70 \%$ das terras que têm sido distribuídas desde 1979 , no entanto, são resultados de mobilizações empreendidas por grupos camponeses que não eram ligados ao MST. Este é particularmente o caso da Região Amazônica onde quase $75 \%$ da distribuição de terras no Brasil têm ocorrido. Incluindo tudo, desde 1979, o Estado brasileiro atribuiu próximo a 30 milhões de hectares para a reforma agrária - um território do tamanho da Itália. ${ }^{15}$ A grande maioria dessas distribuições de terra tem resultado das lutas camponesas.

O MST ganhou ampla visibilidade nacional em meados da década de 1990, por meio do aumento substancial da mobilização por terras depois de 1995 e ampla cobertura da mídia de acontecimentos dramáticos no meio rural. Durante esse período, os meios de comunicação de massa deram considerável atenção para uma série de ocupações de terras no Pontal do Paranapanema, uma área localizada na parte mais ao oeste do estado de São Paulo, o mais rico e mais populoso estado do Brasil. Dois massacres de camponeses sem-terra na região da Amazônia sensibilizaram ainda mais a consciência da nação com relação aos problemas agrários. Em agosto de 1995, a polícia executou nove membros de uma organização local de sem-terras, incluindo uma criança de sete anos, em Corumbiara, Rondônia. A repercussão deste evento, não obstante, foi pálida em face do enorme impacto nacional e internacional causado pelo massacre

12 Ver MST (2004a).

${ }^{13}$ A área ocupada pelos assentamentos do MST está registrada em MST (2003).

${ }^{14}$ Estes números cobrem ambos, assentamentos com laços frouxos e estreitos com o MST. Ver Fernandes (2005).

${ }^{15}$ Estes números são baseados em dados fornecidos pelo escritório em Brasília do Instituto Nacional de Colonização e Reforma Agrária (INCRA) em julho de 2003. Ver MDA, INCRA, SND (2003). Meus cálculos para a Região Amazônica incluem todos os estados que fazem parte da oficialmente chamada "Amazônia Legal". 
policial de 19 camponeses do MST em Eldorado dos Carajás, Pará, em abril de 1996. As fotografias e imagens televisadas desse evento levaram a uma ampla condenação pública do banho de sangue promovido pela polícia estadual. Este episódio, em particular, estimulou o interesse e a simpatia nacional pelo movimento dos sem-terra. Somando-se a este ímpeto, dois meses mais tarde, a importante Rede Globo levou ao ar "O Rei do Gado", uma novela muito popular que ofereceu uma representação positiva, embora paternalista, da luta dos sem-terra. Juntos, estes acontecimentos reforçaram a notoriedade pública do MST e seu reconhecimento geral como principal movimento social do Brasil. Até abril de 1997, pesquisas de opinião mostraram que $94 \%$ da população achavam que a luta do MST pela reforma agrária era justa e $85 \%$ apoiavam ocupações de terras nãoviolentas como uma forma de acelerar os esforços do governo para a reforma agrária. ${ }^{16}$

Não obstante, ao contrário do que é freqüentemente mostrado na mídia, ora temido pelo senso de paranóia da direita, ora romantizado por idealistas da esquerda, o MST não representa uma força de grande poder no cenário político do país. De fato, ele é uma organização de pessoas pobres, operando com recursos escassos e com muitos problemas de ações coletivas que são usualmente encontrados em organizações populares deste tipo. Na verdade, o poder atual do MST decorre em parte grandemente de sua superexposição pela mídia. Suas ações expressivas e os pronunciamentos incisivos feitos por seus líderes, tornam-no merecedor da atenção regular da imprensa. Em parte, isto tem resultado da habilidade crescente do movimento em gerar sua própria publicidade. No entanto, em geral, a cobertura do MST pela mídia tem sido em sua maior parte negativa, e às vezes abertamente hostil. Os mitos e equívocos a respeito do MST construídos pela imprensa brasileira não podem ser subestimados. ${ }^{17}$

\footnotetext{
${ }^{16}$ Estes números são do lbope, um das agências líder em pesquisas do Brasil, e foram publicados pelo jornal O Estado de São Paulo em 16 de abril de 1997. Os dados da pesquisa do Ibope para o ano de 2000 revelaram que $91 \%$ da população continuavam a dar apoio à reforma agrária, enquanto $63 \%$ viam o MST em termos favoráveis, veja Comparato (2003: 190-191).

${ }^{17}$ Relatos informativos de como a mídia brasileira retrata o MST, podem ser encontrados em Berger (1998) e Comparato (2003). Carlos Wagner, um repórter veterano em assuntos de reforma agrária para um dos jornais de grande penetração do sul do Brasil, Zero Hora, alega que este jornal adotou uma decisiva posição anti-MST no início dos anos 90, permanecendo um crítico conservador do movimento desde então. Carlos Wagner, entrevista registrada pelo autor em Porto Alegre, RS, em 01 de julho de 2003. Mais detalhes deste assunto podem ser levantados dando-se uma olhada na cobertura do MST em uma das revistas semanais que mais vendem no Brasil, Veja, em edição discutida com mais detalhes a seguir, na nota de número 48.
} 
O poder do MST, ainda que virtual em certos aspectos, é mais do que uma simples manifestação imaginária. Sete fatores ajudam a explicar suas reais fontes de poder. Em primeiro lugar, o movimento possui uma grande quantidade de membros e uma engenhosa habilidade para mobilizar um volume importante de pessoas. Atualmente, há mais de um milhão de adultos que se identificam como membros do MST. ${ }^{18}$ O movimento tem sido responsável por algumas das maiores mobilizações e protestos populares na história recente do Brasil. Em abril de 1997, por exemplo, o MST convocou uma grande marcha nacional a Brasília, no primeiro aniversário do massacre de Eldorado dos Carajás. O evento mobilizou dezenas de milhares de pessoas de um lado a outro do país. No último dia, as três colunas da marcha convergiram para a capital da nação vindas dos mais distantes cantos do país, reunindo uma multidão de 100.000 pessoas em frente do Congresso Nacional - uma das maiores manifestações na história de Brasília. ${ }^{19}$

Em segundo lugar, desde sua criação, o MST não tem somente desenvolvido uma sofisticada estrutura organizacional e afiado sua capacidade estratégica, mas também tem desenvolvido meios engenhosos para lidar com problemas logísticos. Através dos anos, o movimento tem mostrado uma destacada capacidade para inovação e a habilidade de aprender com os erros do passado. A inventividade do MST é mais clara na forma como seus ativistas locais planejam e executam suas, em geral, arriscadas ocupações de terras - mobilizações não-violentas de massa, as quais são conduzidas com uma precisão quase militar. O movimento também tem sido criativo em seus esforços para levantar fundos. No Rio Grande do Sul, por exemplo, o MST estabeleceu uma cooperativa de trabalho para dar suporte aos acampamentos dos semterra. Organizada em 1996, a Cooper-Tchê oferece trabalhadores para empresas do

\footnotetext{
${ }^{18}$ Este número é sem dúvida precário. O MST não tem uma lista formal de associados e nenhuma pesquisa jamais foi elaborada para quantificar os reais membros do movimento. Em junho de 2004, o MST alegou ter ajudado a assentar próximo de 350.000 famílias, enquanto mobilizava um adicional de 160.000 famílias em acampamentos por todo o Brasil. Baseado nesses números, um cálculo conservador de dois adultos por família, estimaria em um milhão ou mais de membros. Os números do MST são do MST (2004 a). Entre os membros do movimento, os níveis de comprometimento com a organização são variáveis. A perspectiva de uma relação duradoura é fortalecida pelas experiências em mobilização do MST, notadamente em seus acampamentos de sem-terra. O MST é bem conhecido por seus esforços para nutrir uma forte identidade e senso de orgulho entre seus seguidores.

${ }^{19} \mathrm{Um}$ relato completo dessa marcha pode ser encontrado em Chaves (2000); e Dos Santos, Ribeiro e Meihy (1998).
} 
agronegócio, como a agroindústria da maçã, e dedica uma parte dos ganhos ao apoio às pessoas nos acampamentos dos sem-terra e para cobrir seus custos com as mobilizações. Em 2000, o lucro líquido da Cooper-Tchê alcançou US\$ 400.000, um quarto do que foi usado para financiar as atividades gerais do MST no Rio Grande do Sul. ${ }^{20}$

Em terceiro lugar, a coordenação nacional do movimento, suas instâncias descentralizadas e lideranças orgânicas, o permitem funcionar de uma maneira coesa ainda que flexível. O MST conta fundamentalmente com voluntários. Não é uma organização burocrática, mesmo que através dos anos tenha aumentado o seu nível de profissionalismo. Hoje, o escritório nacional e os escritórios estaduais do MST têm empregados regulares, embora recebam salários baixos. Ainda que sincronizado e consistente em muitas de suas táticas, o movimento permite a variação e a experimentação regional. Seus líderes são essencialmente de origem camponesa. Eles residem em geral em assentamentos rurais, vivem modestamente, e mantêm laços próximos com as suas bases. ${ }^{21}$

Em quarto lugar, o movimento tem colocado uma forte e inigualável ênfase na educação de seus participantes e quadros. Isto distingue o MST dos outros movimentos camponeses na América Latina. Nos dias atuais, o MST dirige uma rede de 1.800 escolas primárias e secundárias, freqüentadas por 160.000 crianças. Seus 3.900 professores usam métodos pedagógicos inspirados em Paulo Freire e materiais de ensino desenvolvidos pela própria equipe de educadores do MST. Além disso, o MST estabeleceu um programa de alfabetização para adultos, atualmente servindo a 30.000 pessoas. ${ }^{22} \mathrm{O}$ movimento tem investido muito na preparação de seus quadros, criando vários centros de treinamento para isso. Nos últimos vinte anos, o movimento promoveu centenas de encontros e seminários abrangendo os mais variados assuntos -tais como saúde, educação, gênero, economia política, ecologia- para mais de 100.000 ativistas. ${ }^{23}$ No início de 2005, o movimento inaugurou sua primeira universidade, a Escola Nacional

\footnotetext{
${ }^{20}$ Este relato é baseado em entrevista conduzida com o mentor original da Cooper-Tchê, Antoninho Juscelino Mattes, entrevista registrada pelo autor, em Porto Alegre, RS, em 25 de novembro de 2000 e Viamão, RS, em 09 de julho de 2003.

${ }_{21}$ Para uma relevante discussão da liderança do MST ver, Petras e Veltmeyer (2001).

${ }^{22}$ Ver MST (2004b). Para textos chave sobre a abordagem do MST em educação ver, Kolling, Cerioli, Caldart (2002); Caldart (2000); e Kane (2001) para uma revisão comparativa da educação popular na América Latina.

${ }^{23}$ Ver Carvalho (2005:24).
} 
Florestan Fernandes, nome dado em homenagem a um renomado intelectual brasileiro, com um atraente campus próximo à cidade de São Paulo.

Em quinto lugar, o MST conta com o apoio de uma rede de importantes aliados na sociedade civil e na sociedade política brasileira. Além disso, o movimento tornou-se adepto em trabalhar com simpatizantes dentro do Estado brasileiro, incluindo aquele existentes no INCRA. O apoio da sociedade civil ao MST envolve uma variedade de atores, os mais notáveis dentre eles são setores da Igreja Católica e das denominações protestantes tradicionais, sindicatos de trabalhadores urbanos e rurais, Ongs progressistas, e pessoas ligadas aos estabelecimentos educacionais e culturais do país. No interior da sociedade política, historicamente, o movimento tem desfrutado do apoio do Partido dos Trabalhadores (PT) e outras forcas progressistas. O MST tem também se beneficiado de financiamentos globais à sua causa advindos principalmente de agências ligadas a igrejas na Europa. Além disso, ele tem recebido muitos reconhecimentos nacionais e internacionais, tais como o Prêmio Nobel Alternativo em 1991, e o Prêmio Rei Balduíno, conferido pelo governo da Bélgica em 1996. O movimento mantém laços com muitas organizações ao redor do globo, incluindo grupos solidários ao MST, estabelecidos em 14 países da Europa e da América do Norte. Por meio de sua afiliação à Via Campesina, uma coalizão internacional de camponeses, o MST mantém contato com organizações de pequenos produtores em 43 nações.

Em sexto lugar, apesar de ser uma organização de pessoas pobres, o MST é dotado de um modesto suprimento de recursos materiais - veículos, escritórios, computadores, celulares e similares - necessários para manter seus compromissos básicos. Seus recursos financeiros provêm das mais variadas fontes. Isto inclui dinheiro para desenvolver projetos administrados pelo movimento, disponibilizados por governos estadual e nacional, bem como por agências internacionais. Além disso, o MST recebe contribuições de suas cooperativas e membros, através de taxas informais, usualmente de 2 a $3 \%$ de sobretaxa sobre créditos agrícolas obtidos do governo federal. Os acampamentos dos sem-terra normalmente garantem sua alimentação através de uma combinação de contribuições, tais como doações do INCRA, do governo local e estadual, famílias e amigos, e assistência de uma série de simpatizantes dentro da sociedade civil, incluindo igrejas, sindicatos de trabalhadores e Ongs. Em geral, o MST é mais bem 
provido na região sul do Brasil e mais pobre nas regiões menos desenvolvidas do norte e nordeste do país.

Em sétimo lugar, os interesses ideais que permeiam aspectos substanciais da organização geram um forte senso de identidade, uma intensa energia social e vigorosas conviç̧ões, particularmente entre os militantes do movimento. As lutas do MST são conduzidas por mais que apenas interesses materiais. Boa parte de seu ímpeto deriva daquilo que Max Weber define como uma ação social orientada por interesses ideais (ou uma racionalidade valorativa). Atores motivados por interesses ideais são orientados estrategicamente a seguir e cumprir um objetivo absoluto, não negociável. As mobilizações do MST são freqüentemente imbuídas por esta qualidade. O comportamento orientado por interesses ideais é caracterizado por uma mistura de empenho e realização, mais do que maximização estratégica. ${ }^{24}$ Ele gera sentimentos fortes que resultam de e impulsionam suas mobilizações de massa. Suas interações coletivas alteram poderosamente o cálculo individual e a tomada de decisão de seus membros. Além disso, eles exibem regularmente um repertório simbólico denso - com bandeiras, canções, declamações, palavras de ordem, marchas, teatros, e outras práticas rituais - que inspiram coragem e vitalidade entre seus participantes. Os membros do MST descrevem estes momentos como parte componente de sua "mística". Em conversas com militantes do movimento não é incomum ouvi-los transmitindo expressões de forte apego emocional, tais como: "Eu amo o MST", "O MST é minha vida". ${ }^{25}$

\footnotetext{
${ }^{24}$ Para uma breve caracterização de Weber sobre o comportamento racional de valor ver Weber (1978:24-26). O conceito de "fusão de empenho e realização" vem de Alberto O. Hirschman $(1982: 85)$

${ }^{25} \mathrm{O}$ conceito de interesse ideal do Max Weber é tratado extensivamente em Carter (2005b, 2003). Outras análises de movimentos sociais que enfatizam a importância desse compromisso apaixonado podem ser encontradas em Goodwin, Jasper e Poletta (2001); e Aminzade e McAdam (2001).
} 


\section{Engajando o Processo Democrático: O Ativismo Público do MST e as Instituições Políticas do Brasil}

As relações do MST com o sistema político brasileiro são complexas, multifacetadas e dinâmicas. Isto se deve muito à variada estrutura do Estado brasileiro, incluindo as suas múltiplas instâncias de decisão, as suas instituições descentralizadas, e a grande diversidade de formas e pontos de acesso à administração publica. O regime federalista do Brasil, a sua tradição de governos municipais relativamente fortes, seu sistema eleitoral particular e a sua intrincada burocracia estatal, desempenham um papel chave na moldagem do repertório de ações coletivas do MST. Em qualquer situação, a escolha tática do movimento será determinada em grande parte pelas oportunidades percebidas e os desafios em questão. Na linguagem do MST, seu conjunto de opções estratégicas emerge de suas próprias "análises de correlação das forcas sociais e políticas". Esta parte do texto oferece uma breve síntese dos principais padrões de envolvimento do movimento com as instituições políticas brasileiras - o ativismo público e atos de desobediência civil do MST, o lobby e as negociações, o corporativismo social ad hoc, a participação eleitoral, e as suas relações diversas com o Estado de Direito.

Ativismo Público. O MST é bem conhecido por suas políticas contestatórias, particularmente por sua agitação e mobilização social. Algumas destas mobilizações envolvem atividades legítimas de protesto, protegidas pela lei. Outras atividades envolvem táticas de ação direta e desobediência civil. O ativismo público refere-se a uma forma específica de conflito social caracterizada por ser: organizada, politizada, visível, autônoma, recorrente e basicamente não-violenta. Este padrão de política contestatória é posto em ação essencialmente para atrair a atenção pública, influenciar as políticas do Estado, e moldar as idéias, valores e ações da sociedade. ${ }^{26}$

A inclinação do MST para o ativismo público é levada a curso por meio de uma série de atividades de protesto. A maioria delas inclui manifestações lícitas tais como marchas, que podem se estender por várias centenas de quilômetros, usualmente

\footnotetext{
${ }^{26}$ Tipicamente, mobilizações deste tipo empregam uma série de modernos repertórios de contestação - isto é, marchas, piquetes, petições, reuniões de grupo, paralisações, ocupações de prédios, ocupações organizadas de terras, comícios, greves de fome, bloqueio de estradas, acampamentos de protesto, e campanhas eleitorais. Sobre este assunto, ver Tarrow (1998) e Tilly (1983. 1979).
} 
para a capital do estado, ou até mesmo para Brasília; greves de fome; e a organização de acampamentos de sem-terra, geralmente nas margens de rodovias públicas, em áreas autorizadas pelo Estado, ou em propriedades privadas que pertencem a simpatizantes do MST tais como a Igreja ou algum fazendeiro caridoso. Esses acampamentos de semterra, com a suas tendas provisórias de plástico, seu estilo de vida bem organizado e disciplinado, e bandeiras vermelhas do MST tremulando no alto, são talvez as mais visíveis, bem conhecidas e engenhosas ações de contestação do MST. Os acampamentos não apenas tornam a demanda por reforma agrária perceptível, eles também facilitam as atividades de conscientização entre os sem-terra, possibilitam a preparação de outras mobilizações de protesto, e são úteis ao movimento no recrutamento e treinamento de seus novos quadros.

Desobediência Civil. As táticas mais controversas empregadas pelo MST envolvem atos de resistência passiva às leis civis. Entre essas formas de ativismo público estão principalmente: ocupações de terras privadas ou públicas, ocupações de prédios do governo e bloqueios de rodovias. Ocasionalmente, defrontados com a fome e calamitosa necessidade, alguns acampados do MST têm parado e saqueado alguns caminhões que transportam alimentos, uma tática limitada, sobretudo ao interior pobre do nordeste brasileiro. Estas formas de mobilização do MST são essencialmente de massa, não-violentas, ainda que utilizem táticas fortes e enérgicas. Com freqüência, estas ações violam leis convencionais, notadamente aquelas que protegem os direitos de propriedade. A tolerância ou repressão por parte do Estado a essas formas de protesto depende principalmente da orientação política de autoridades relevantes, especialmente dos governadores que controlam a polícia, e outras autoridades responsáveis pela defesa e aplicação da lei. Despejos violentos por parte da polícia das ocupações de terras e edifícios não são incomuns. Contudo, a maioria dos atos de desobediência civil do MST termina de forma pacífica, geralmente como resultado de extensas negociações com autoridades policiais, judiciais e políticos. Estas mobilizações de protesto são invariavelmente acionadas visando tornar públicas uma determinada demanda e, deste modo, trazer as autoridades do Estado para a mesa de negociações.

O uso da desobediência civil e de outras táticas não-violentas por parte do MST não é acidental. De fato, seu ativismo público é condicionado pela presença de 
um Estado relativamente forte, oportunidades políticas para protestos sociais, e o acesso a recursos substanciais para tais mobilizações. Este meio cria incentivos que predispõem o movimento a barganhar com autoridades do Estado e a construir parcerias com outros atores da sociedade civil e política. O ativismo público do MST, por conseguinte, é substancialmente diferente de outras formas de conflito social, tais como insurgências armadas, os distúrbios violentos, e o que James C. Scott descreve como "formas de resistência cotidianas", para descrever atos informais e disfarçados de agressão social. ${ }^{27}$ Distinta destes tipos de conflito social, as ações visíveis, organizadas, politizadas e nãoviolentas do MST fazem-se compatíveis com a sociedade civil e um regime democrático.

Lobby e Negociação. As táticas de pressão do MST não emergem do vácuo, mas antes num contexto de petições frustradas e de negociações em andamento com autoridades públicas. Estas negociações podem ser feitas nos vários níveis de governo, local, estadual ou nacional. Os mais freqüentes interlocutores do MST são os funcionários do Ministério do Desenvolvimento Agrário e, especialmente, sua agência de reforma agrária, o INCRA. Isto se origina do fato de as leis de reforma agrária do Brasil serem relativas ao governo federal. Se o assunto, não obstante, é conseguir desembolso de dinheiro público em tempo, o alvo para a insistência e barganha do MST, pode ser o Banco do Brasil ou o Ministério da Fazenda. Desde 1993, o MST tem tido reuniões regulares com razoável freqüência com todos os presidentes do Brasil.

Corporativismo Social Ad Hoc. Ainda outro modo de interação com o Estado brasileiro sugere a existência de um modelo emergente de representação de interesses baseado em relações mais horizontais (do que subordinadas) no acesso a recursos do Estado e suas instâncias de execução de políticas publicas. Ainda que frouxamente organizado e de alcance limitado, este modelo de representação social exprime pautas diferentes ao modelo de corporativismo do Estado instaurado no Brasil sob o "Estado Novo" do Presidente Getúlio Vargas. ${ }^{28}$ Através dos anos, o MST tem

\footnotetext{
${ }^{27}$ De acordo com Scott, as "formas de resistência cotidiana" incluem atos agressão como a caça e a pesca furtiva, o roubo dissimulado de alimentos, a evasão, as ameaças anônimas, atos de sabotagem e incêndio criminoso. Veja, Scott (1985, 1990); também Collbum (1989).

${ }^{28}$ Meu uso de "corporativismo social" segue a distinção clássica de Philippe C. Schmitter (1974) entre o "corporativismo do Estado" (baseado em relações verticais com as organizações da sociedade) e o "corporativismo social" (conformado por relações horizontais com entidades da sociedade civil). O corporativismo do Estado não é compatível com a democracia liberal, mas o corporativismo social é.
} 
assinado um número de acordos formais com o governo federal e entes públicos para realizar uma variedade de projetos de desenvolvimento, notadamente no campo da educação e da saúde. Em 2004, por exemplo, o movimento construiu uma planta para processar produtos de medicina natural, no estado do Ceará, com apoio da Petrobrás, a empresa estatal de petróleo. Além disso, representantes do MST têm sido convidados ocasionalmente para fazer parte de comissões do governo para estabelecer, por exemplo, diretrizes para a distribuição de créditos para os novos assentados da reforma agrária. Em outros momentos, líderes do movimento têm participado da administração de algum governo local ou ainda ajudado a dirigir agências do Estado. Por exemplo, quando o PT ganhou o governo do Rio Grande do Sul em 1998, ele convidou o MST para dirigir a agência de desenvolvimento rural, responsável pela reforma agrária. Em alguns locais, os membros do MST tem tido um papel ativo nos conselhos municipais, lidando com saúde, educação e outros assuntos relativos ao bem-estar da população. Este modelo de representação de interesses, é necessário ressaltar, tem surgido somente sob condições políticas específicas e resultado em limitados compromissos políticos. De um modo diferente da experiência corporativista social dos sindicatos de trabalhadores na maior parte da Europa Ocidental, o Brasil não tem criado estruturas nacionais para incorporar o MST em relevantes processos de elaboração de políticas publicas.

Participação Eleitoral. Desde a sua origem, o MST tem participado ativamente em campanhas eleitorais e outras atividades vinculadas a partidos políticos. Seus antigos laços com o PT são bem conhecidos. Embora ambas as associações compartilhem muitos de seus membros, eles têm tradicionalmente dirigido suas organizações autonomamente. Esta independência deve-se, em boa parte, ao fato de que o MST foi fundado separadamente do PT. Isto foi reforçado por uma decisão assumida pelo PT desde a sua fundação: a de evitar subordinar os movimentos sociais ao partido, diferenciando-se das concepções ideológicas da esquerda tradicional. Laços entre o PT e MST foram consolidados na metade da década de 1980 com a formação da Secretaria Agrária Nacional do partido e o Núcleo Agrário da Câmara dos Deputados. Ambos os grupos ofereceram um espaço para diálogo e formulação de políticas que aproximaram membros do PT, representantes do MST, líderes de sindicatos rurais, e porta-vozes de outras organizações progressistas da sociedade civis. Em tempos de necessidade, 
membros do PT têm costumeiramente dado apoio aos militantes do MST. O PT e o MST geralmente convergem fortemente quando ambos, partido e movimento, se opõem às autoridades do governo. A relação torna-se mais problemática quando o PT é o partido do governo, como é a atual situação com a presidência de Lula. Em geral, estas tensões têm sido parcialmente temperadas pela própria sagacidade política do MST, incluindo sua habilidade para diferenciar entre os adversários e aliados no governo Lula.

Nem todas as pessoas filiadas ao MST apóiam o PT. Em numerosos lugares, particularmente na região norte e nordeste do Brasil, muitos camponeses ainda estão engajados em políticas clientelistas. Com poucas exceções, os quadros do MST têm aderido ao PT, e dentro do PT a tendência tem sido se identificarem com as facções mais à esquerda do partido. Sempre que possível, o MST tentará indicar os seus próprios candidatos no PT para o governo local, embora eles também tenham sabido assumir compromissos com outros partidos políticos. No Rio Grande do Sul, o MST tem sido capaz de eleger um Deputado Federal por quatro mandatos e um representante para a Assembléia do Estado.

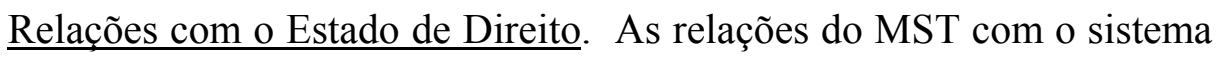
legal são um assunto de longa controvérsia no Brasil. A prevalecente ortodoxia neste país supõe que as ocupações de terra e edifícios pelo MST estão em conflito com o Estado de Direito, e são um sinal do desdém que o movimento teria em relação ao Estado de um modo geral. Esta visão, no entanto, distorce o que é uma relação bem mais complexa. Ignora-se o fato de que o sistema judiciário brasileiro é extremamente burocrático, a ponto de comprometer o seu desempenho, e impregnado com notáveis preconceitos de classe. Isto explicaria muita das dificuldades do MST em lidar com o sistema legal. ${ }^{29}$ Além do mais, os atos do movimento de desobediência civil exprimem muitos elementos constitutivos de uma ordem legal alternativa. Como muitos dos movimentos sociais ao redor do mundo e na história, o MST está muito envolvido em disputas sobre a aplicação e a interpretação da lei. A nova constituição de 1988, por exemplo, assegura a reforma agrária e qualifica os direitos de propriedade pela sua

\footnotetext{
29 Um relato esclarecedor sobre a ineficiência e o viés classista de instituições legais latinoamericanas, com amplas referências ao Brasil, pode ser encontrado em Mendez, O'Donnell e Pinheiro (1999).
} 
função social. Apesar destas provisões da lei, a maioria dos juízes insiste em aplicar a abordagem absolutista do Código Civil para os direitos de propriedade e, desta forma, acabam criminalizando os militantes do MST.

Em uma importante vitória para o movimento, uma decisão de 1996 do Superior Tribunal de Justiça determinou que as ocupações de terras concebidas para acelerar reformas eram "substancialmente distintas" de atos criminais contra a propriedade. Este pronunciamento reconheceu de certa forma, a legitimidade dos atos de desobediência civil do movimento. Longe de simplesmente desdenhar a legalidade, o MST tem ativamente contribuído para moldar o debate sobre a natureza e função da lei. De fato, o movimento regularmente procura influenciar as decisões nos altos escalões do judiciário. Ele possui uma ativa e ampla rede de advogados dispostos a assumir esses casos, tanto quanto debater e avançar conceitos legais. Além disso, suas ocupações de terras são freqüentemente planejadas tendo assuntos legais em mente, tendo na mira, por exemplo, fazendas de propriedade ilícita ou duvidosa. ${ }^{30}$

Todas essas considerações - a disposição do MST para o ativismo público e as suas táticas de desobediência civil, o lobby e as negociações com autoridades públicas, sua orientação em favor de um corporativismo social, seus envolvimentos eleitorais e intricadas relações com o Estado de Direito - realçam a complexidade das relações do MST com as instituições políticas do Brasil. De fato, elas demonstram que por toda sua dura retórica, o MST não é um movimento "anti-Estado", como alguns analistas nos fazem acreditar. ${ }^{31}$ Pelo contrário, o MST tem repetidamente tomado posições que favorecem um Estado forte, nacionalista e desenvolvimentista, orientado para os interesses do setor popular. Estas visões são exemplificadas pela firme oposição do movimento às políticas de privatização dos governos Collor e Cardoso; suas repetidas chamadas para uma moratória da dívida externa; sua forte demanda pela extensão de políticas públicas de bem-estar social; e reiterados pedidos por adequados recursos públicos para viabilizar a reforma agrária, mediante o financiamento das atividades do INCRA, e a contratação de funcionários públicos para executá-las.

\footnotetext{
${ }^{30}$ Minhas observações sobre as relações do MST com as regras da lei são devidas grandemente a George Meszaros (2005; 2000). Sobre o mesmo tópico ver também Hammond (1999) e o Setor de Direitos Humanos na página de internet do MST (2005),

${ }_{31}$ Veja Navarro (2002a, 2002b), Martins (2003, 2000), Graziano (2004).
} 


\section{Contribuindo para a Democracia: Política de Pressão, Direitos de}

\section{Cidadania e Utopia}

Ao longo da sua história, o MST tem tido mais sucesso em moldar a agenda política do Brasil e impulsionar ações de reforma agrária do que em efetuar mudanças via participação eleitoral. As mobilizações populares e a "política de pressão" tem sido o modo principal de o MST engajar-se com as instituições democráticas brasileiras. Processos eleitorais, embora nunca irrelevantes para o movimento, têm normalmente assumido menor importância em face de outras táticas mais diretas e assertivas. Como um ator da sociedade civil, o MST tem sido principalmente orientado para influenciar as políticas do Estado em vez de controlar o próprio aparato do Estado. Em outras palavras, sua demanda tem sido guiada primordialmente para alcançar o "accountability social” das autoridades governamentais. 32

O MST nasceu e foi criado no meio de conflitos sociais. "A gente tem que lutar" é uma lição aprendida desde as origens do movimento. Esta idéia tornou-se profundamente enraizada no ethos do movimento e em sua própria imagem. $\mathrm{Na}$ fala do dia-a-dia do MST, todas as suas "vitórias" e "conquistas" são o resultado de lutas, não a conseqüência de um legado do Estado ou concessão política. A lição aprendida nos últimos 25 anos de mobilizações dos sem-terra é simples: é preciso pressionar o Estado por meio do ativismo público e então negociar o melhor acordo possível. E depois, lutar para obter o próximo item da agenda através de uma outra rodada de ativismo público.

A política de pressão do MST, embora enraizadas, não é o resultado de mera suposição ideológica, como insistem alguns críticos do movimento. Zander Navarro, por exemplo, sustenta que o MST tem "canonizado" a ação coletiva como resultado de sua visão "fundamentalista" da política, nutrida por idéias que ele descreve como sendo de um "marxismo vulgar". ${ }^{33}$ Dadas as opções disponíveis, porém, a

32 De acordo com Smulovitz e Peruzzotti, o "accountability social" é um "mecanismo vertical de controle que," ao contrário da accountability eleitoral, "apóia-se nas ações de uma múltipla série de associações de cidadãos e movimentos e através da mídia." Suas ações empregam ferramentas institucionais e extra-institucionais para "expor as ações erradas do governo, trazer novas questões para a agenda pública ou ativar a operação" de agências responsáveis pela accountability horizontal, tais como o segmento judicial (2000: 150).

${ }^{33}$ Navarro (2002b: 261,267, e 279). 
preferência do MST por uma política de pressão é de fato uma estratégia inteiramente racional para maximizar sua eficácia. Considerando os meios alternativos para alcançar seus objetivos -contestação eleitoral, representação legislativa, influência da mídia, lobbying ou revolta armada- a política de pressão é claramente a opção mais razoável e de melhor custo.

As campanhas eleitorais, para começar, exigem muito dinheiro no Brasil, e o MST não tem os fundos necessários para lançar um candidato nacional ou ao governo de um Estado, ou mesmo financiar outros candidatos simpatizantes.

Por outro lado, a representação no Congresso Nacional e nas Assembléias Legislativas de cada estado oferece benefícios limitados. No seu dia-a-dia, as políticas agrárias são essencialmente controladas pelo Poder Executivo. As Assembléias estaduais, em particular, têm muito pouco poder para legislar sobre assuntos agrários devido a estes assuntos estarem sob a competência do governo federal. Além disso, o Congresso Nacional, ao longo da sua história, tem sido um grande obstáculo para iniciativas progressistas em matéria de reforma agrária. Isto se deve à grave sobrerepresentação de parlamentares ligados aos interesses dos grandes proprietários de terras. ${ }^{34}$ Como resultado, desde a redemocratização, a maior bancada no Congresso tem sido a conservadora "bancada ruralista". Esta coalizão multipartidária representada por membros da elite rural conta com a adesão de cerca de $40 \%$ do Congresso Nacional. ${ }^{35} \mathrm{~A}$ arena legislativa, em suma, oferece poucas possibilidades para ações efetivas de reforma agrária.

As demais alternativas são igualmente impraticáveis. O MST não tem recursos para estabelecer uma importante agência de mídia no Brasil. Anos de experiência têm ensinado ao movimento que lobbying é um instrumento inútil, se não for apoiado por mobilizações populares e outras formas de política de pressão. Finalmente, a

\footnotetext{
34 A redemocratização brasileira manteve intactas as disposições de representação eleitoral estabelecidas pelo regime militar, as quais têm favorecido regiões do país onde os grandes proprietários de terras e o clientelismo político tiveram, historicamente, maior peso. De acordo com Alfred Stepan, um voto depositado no subdesenvolvido estado amazônico de Roraima tem 144 vezes mais peso do que um voto depositado em São Paulo, o estado mais industrializado do país (2001:343). Um bom relato histórico dos problemas do Brasil com relação à sobre-representação pode ser encontrado em Snyder e Samuels (2004).

${ }^{35}$ Martins (2005).
} 
alternativa da guerrilha seria uma aposta suicida para o MST. Apesar de uma afeição por Che Guevara e outras figuras revolucionárias mundiais, o caminho da rebelião armada tem sido amplamente descartado pelo movimento. Em suma, nenhuma das opções aqui relatadas oferece uma escolha viável.

O ativismo público e suas táticas perturbadoras da ordem, neste caso, é o único caminho razoável de ação disponível para os camponeses sem terra do Brasil. A política de pressão é antes e sobretudo uma resposta prática, uma medida coletiva visando solucionar problemas concretos - não uma maquinação de uma agenda ideológica. $\mathrm{O}$ ativismo público capacita o MST a mexer com a opinião pública e ganhar acesso direto aos formuladores de políticas públicas de um modo que a maioria dos mecanismos institucionais se tornariam, na melhor das hipóteses, ineficazes ou inócuos.

Visto em termos históricos, o ativismo público do MST representa uma reação corajosa às injustiças persistentes na concentração de terras do Brasil e um esforço sensato no sentido de superar os duradouros obstáculos políticos à reforma agrária. Até os dias de hoje, nenhum governo brasileiro instituiu um amplo programa de reforma agrária. Embora tenha havido uma tendência em direção a uma maior distribuição de terras desde 1995, este desenvolvimento não tem sido suficiente para alterar substancialmente as terras improdutivas do país e as disparidades sociais. ${ }^{36}$ A reforma agrária continua a ter muitos poderosos oponentes no Brasil. Tudo indica que as modernas elites agrárias do país não parecem ser mais receptivas à reforma agrária do que seus tradicionais antecessores. ${ }^{37}$ Certamente, não se pode tomar a atenuada visibilidade das associações

\footnotetext{
${ }^{36}$ A distribuição de terras aumentou consideravelmente durante a presidência de Fernando Henrique Cardoso (1995-2002). Esta tendência atingiu seu apogeu em 1998 e caiu consideravelmente até 2002. Os números de distribuições de terras para o início de 2000 foram, não obstante, notavelmente mais altos do que foram na década anterior. O número estimado de assentamentos de famílias semterra sob a Era Cardoso estaria entre 350.000 e 400.000 , menos de $6 \%$ do total de produtores rurais. Estatísticas da reforma agrária divulgadas pelo Governo Fernando Henrique Cardoso apresentam números consideravelmente mais altos: 600.000 famílias assentadas; um total de 7,6\% das famílias de produtores rurais da nação. Estas estatísticas, todavia, têm sido profundamente questionadas por vários estudiosos e pela imprensa brasileira. $\mathrm{Na}$ verdade, há evidências verossímeis que sugerem que os números do governo foram significativamente aumentados. Para uma visão construtiva deste debate e das realizações sob a Era Cardoso, ver Ondetti (2004).

${ }^{37}$ Segundo Martins (2000:48), a nova elite agrária do Brasil tornou-se disposta a cooperar com a reforma agrária a partir de meados da década de 1990. A avaliação de Martins, não obstante, desconsidera as condições econômicas circunstanciais e a sua incidência pontual no mercado de terras existentes naquele tempo. A bem sucedida estabilização econômica do Plano Real, na metade da década de 1990, unida a uma queda nos preços agrícolas e nas exportações, tanto quanto aos generosos preços pagos pelas terras pelo INCRA, tornou atrativo para os grandes proprietários de
} 
de grandes proprietários de terras, tais como a União Democrática Ruralista (UDR), como um sinal de que a classe latifundiária brasileira tem alcançado níveis de fragilidade sem precedentes. ${ }^{38}$ Ao contrário, os oponentes da reforma agrária têm se mostrado aptos em metamorfosear-se, ao mesmo tempo em que confiam em duradouras redes de poder informal. Hoje, interesses rurais conservadores constituem um variado grupo que inclui poderosos setores do florescente agronegócio brasileiro.

Deparado com uma forte resistência à reforma agrária, o MST tem continuado a gerar pressão social e tem feito isso mesmo após a eleição do presidente Luiz Inácio Lula da Silva do PT, um amigo e simpatizante do MST de muito tempo. Por tudo que ela prometia, a administração Lula tem sido lenta e hesitante para levar adiante a distribuição de terras. Constrangido por uma grande dívida externa, por um apertado orçamento fiscal e por uma coalizão política com setores conservadores, o Governo Lula tem deixado o MST e seus aliados com poucas opções a não ser fortalecer o ímpeto público por mais reforma. Entre o final de março e início de maio de 2004, por exemplo, o MST liderou uma onda de 109 ocupações de terras em diferentes partes do país. Como esperado, estas mobilizações mexeram com a atenção da mídia e incitaram novas promessas, esforços e fundos governamentais para avançar a reforma agrária. ${ }^{39}$

Para o MST, a política de pressão é mais do que somente um instrumento para exigir concessões do governo. $\mathrm{O}$ ato de luta também fortalece a dinâmica interna do movimento. As ações de protesto garantem que o movimento permaneça ativo, e estimulam as emoções e os interesses ideais que dão ao movimento sua extraordinária capacidade de resistência. As mobilizações do MST, particularmente as ocupações de terras, são momentos cruciais na educação dos seus ativistas. De certo

terras venderem suas fazendas para o Estado. Sob estas condições e incentivos, muitos proprietários de fazendas converteram suas terras em lucrativos ativos líquidos e proveram o Governo Fernando Henrique Cardoso com um estoque de terras para redistribuição. Esta conjuntura particular terminou em 1999 com a desvalorização do Real. Ao contrário das observações de Martins, as modernas elites agrárias têm estado bem menos favoráveis à "reforma agrária" nos anos recentes.

${ }_{38}$ Veja os argumentos de Navarro (2002b: 274) sobre a "fragilidade" da classe latifundiária. As análises de Navarro ignoram o fato de que o status atenuado da UDR nos anos 1990 foi um efeito combinado de seu sucesso no final da década de 1980 e sua própria desorganização no início da década de 1990. A dissolução de classe não teve um papel relevante na decadência da UDR. Para uma sólida análise da história da UDR e sua crise interna, ver Payne (2000). Através do Brasil, muitas associações de grandes proprietários de terras têm permanecido particularmente fortes e ativas no nível estadual e local.

${ }^{39}$ Ver Scolese (2004). 
modo, eles constituem os "batismos de fogo" do MST. Estas poderosas experiências, junto com intensos workshops educacionais, permitem ao movimento produzir novas gerações de ativistas. $\mathrm{O}$ ativismo público, em outras palavras, favorece o capital social do movimento e mantém vivos seus compromissos ideais e sua energia social.

Longe de ser um sinal de "incongruência" e afronta à democracia, ${ }^{40} \mathrm{a}$ política de pressão do MST e toda a retórica severa que geralmente vem com ela, deveriam ser apreciadas como uma marca de compromisso e vitalidade democrática. A democracia requer uma ativa e engenhosa sociedade civil. As mobilizações do MST têm feito muito para aumentar e fortalecer a sociedade civil em muitas áreas rurais, organizando e incorporando setores marginalizados da população dentro desta arena social. Além disso, suas manifestações de protesto em uma série de questões -tais quais o uso de sementes geneticamente modificadas, violações dos direitos humanos nas zonas rurais, e o modelo de desenvolvimento da economia atual- têm enriquecido o debate público no Brasil e atraído a atenção para problemas profundos do país em relação à injustiça social.

Em suma, o ativismo público e suas táticas de pressão representam um instrumento eficaz e um processo pedagógico inspirador para o MST. Eles proporcionam muitas de suas conquistas, ao passo que instalam um senso de orgulho, dignidade e pertencimento entre aqueles envolvidos em suas mobilizações. Nisto repousa uma fonte adicional da força do MST: uma capacidade para equilibrar seus firmes ideais com soluções pragmáticas para seus problemas cotidianos. Esta peculiar interação capacita o MST a se mobilizar com grande ímpeto e, ao mesmo tempo, negociar com uma engenhosa habilidade.

O MST tem sido um participante importante no desenvolvimento dos direitos de cidadania no Brasil -em todas as três dimensões contemporâneas desta idéia: direitos civis, políticos e sociais. ${ }^{41}$ Desde sua origem, o MST tem lutado pelo direito de se mobilizar livre e autonomamente, e exercitar seus direitos democráticos para influenciar as decisões tomadas pelas autoridades públicas, independentemente do processo eleitoral. Através de medidas legais e esforços de divulgação pública, têm

${ }^{40}$ Para tal descrição do MST, ver Navarro (2002a: 219).

${ }^{41}$ Como esboçado originalmente por T. H. Marshall (1992). 
defendido os direitos humanos básicos de centenas de camponeses que têm sido presos, maltratados e assassinados por suas atividades em favor da reforma agrária. As lutas e conquistas do MST têm também inspirado muitas outras mobilizações populares, ambos, nas zonas rurais e entre os pobres urbanos. Muitos movimentos populares no Brasil - de mulheres camponesas aos atingidos pela construção de barragens hidrelétricas, aos pequenos agricultores, sem-teto, e outros grupos de sem-terra- têm assimilado as táticas e emprestado coragem do MST para agir. ${ }^{42}$ Ao fazer isto, o MST tem ajudado a estimular setores populares do Brasil e auxiliado na sua "transição do clientelismo para a cidadania". ${ }^{43}$

Através dos anos, o MST tem promovido numerosas conquistas - cerca de 2.300 assentamentos de reforma agrária para 350.000 famílias, 88 cooperativas, 1.800 escolas, programas educacionais inovadores e novas iniciativas em agro ecologia. Melhorando as condições materiais e recursos culturais de seus membros, o movimento tem fortalecido os fundamentos sociais para a democracia. Quando as necessidades básicas são atendidas, as pessoas são menos propensas a venderem seus votos no dia da eleição. De fato, o senso de caráter e dignidade forjado ao longo de anos de luta do MST tem nutrido cidadãos mais conscientes e promovido uma maior participação pública em assuntos locais. Ao capacitar as pessoas a usarem seus direitos políticos, o MST tem ajudado a integrar centenas de milhares de brasileiros pobres e historicamente marginalizados no processo democrático.

As reivindicações do MST em favor da implementação das leis nacionais de reforma agrária são ilustrativas dos esforços do movimento em superar dois grandes abismos na sociedade brasileira: os graves contrastes entre pobres e ricos, e a notável distância entre os direitos sociais consagradas na Constituição e a sua fraca execução. O primeiro objetivo é corrigir níveis de desigualdade que colocam o Brasil como a segunda sociedade mais desigual no mundo, e tem levado, de fato, à formação de um verdadeiro Apartheid social. O segundo objetivo busca diminuir o abismo histórico entre o país legal e o país real - entre o edifício formal do país (feito "para inglês ver," como assinala o ditado popular) e sua realidade cotidiana. A insistência do MST na

\footnotetext{
${ }^{42}$ Ver Rosa (2005).
}

${ }^{43}$ Ver Fox (1994). 
efetivação de garantias constitucionais progressistas tem sido um instrumento efetivo para promover os direitos sociais. Desta forma, tem-se criado um modelo realístico de como os pobres podem tornar-se agentes de seu próprio desenvolvimento. A experiência do MST mostra que a participação de grupos de base em programas de desenvolvimento não é uma mera questão técnica, mas algo que está emaranhado nas relações de poder e de um impacto político inevitável. Este fenômeno, contudo, é algo que não causa surpresa para os estudiosos dos direitos de cidadania. Como Charles Tilly nos lembra, estes direitos têm sido construídos historicamente através de anos de resistência, luta e negociações com autoridades nacionais - não por gentis concessões das elites governantes ou a gradual ilustração da sociedade com um todo. ${ }^{44}$

Finalmente, o MST contribui para a democracia ao engendrar um senso de utopia e afirmar muitos ideais que são parte do longo e continuado processo de desenvolvimento democrático. Como Giovanni Sartori bem coloca, "o que a democracia $e ́$ não pode ser separado do que a democracia deve ser". Uma democracia existe somente até o ponto em que seus ideais e valores a tornam realidade. ${ }^{45}$ A democracia, em suma, é grandemente empobrecida se despojada dos sonhos e desejos de liberdade, igualdade e participação que a tornaram possível.

O MST tem se engajado ativamente na promoção da mudança social e de um senso de utopia. Em anos recentes, a crença de que "um outro mundo é possível," tem encontrado um ambiente apropriado nas assembléias do Fórum Social Mundial. Esta coligação global de forcas progressistas e alternativas emergiu como um contraponto às reuniões do Fórum Econômico Mundial estabelecido em Davos, na Suíça; um ponto de encontro para as principais lideranças do mundo financeiro, os titulares de grandes corporações multinacionais, e chefes de Estado. O MST tem participado ativamente do Fórum Social Mundial desde o seu primeiro encontro em 2001. Por certo, quatro dos seus cinco encontros até 2005 aconteceram em Porto Alegre, Brasil, não muito longe de onde o movimento nasceu.

O MST progrediu muito desde suas precárias origens no início da década de 1980. Hoje o movimento é um ator reconhecido na florescente reação global

44 Tilly (2002).

45 Sartori (1987: 7). 
contra o neoliberalismo e é uma voz proeminente na demanda por uma maior justiça social e responsabilidade ecológica. Para muitas pessoas ao redor do mundo, o MST tem se tornado um sinal de esperança de que "um outro mundo é possível."

A democratização é um processo continuado e de longo-prazo que não pode se divorciar de seus ideais democráticos. ${ }^{46}$ Como Max Weber perceptivamente escreveu, os seres humanos "não teriam alcançado o possível se repetidamente (eles) não tivessem estendido a mão para o impossível". Uma "firmeza de coração ... pode encorajar até a mais decadente de todas as esperanças. Isto é necessário agora, ou de outro modo (as pessoas) não serão capazes de alcançar até mesmo o que é possível hoje". ${ }^{47}$

Uma democracia que não inspira criatividade, novos horizontes e inovações é uma democracia insípida. O dinamismo, engenhosidade e demanda por uma maior justiça social do MST - em uma nação afligida por notáveis desigualdades sociais - representam uma força vital em favor da democratização. De fato, isto tem sido o papel de muitos movimentos sociais ao redor do mundo e através da história moderna. 48

\footnotetext{
${ }^{46}$ Este ponto é persuasivamente debatido em Whitehead (2002).

${ }^{47}$ A citação é do ensaio de Weber, "Política como uma vocação" (1958: 128).

${ }^{48}$ Sobre a importância histórica dos movimentos sociais para a democracia, ver Markoff (1996). De um modo mais geral, sobre os movimentos sociais e democratização ver Tilly (2004).
} 


\section{Conclusão}

O MST ajuda a fortalecer a democracia no Brasil? A resposta até agora deveria ser completamente evidente. Sim, fortalece, mas não através dos principais meios convencionais da democracia liberal. O contexto brasileiro é crucial para entender isto.

A iniciativa para a reforma agrária no Brasil provém fundamentalmente de um ímpeto social. Ela tem experimentado altas doses de conflito e custado centenas de vidas. A impunidade sobre essas mortes tem sido espantosa. De acordo com a CPT, a principal organização rural de direitos humanos do Brasil, entre 1985 e 2003, 1.349 camponeses, incluindo dúzias de crianças, foram mortos em diferentes conflitos rurais. Somente 76 destes assassinatos, 5,6\% do total, foram levados a julgamento. Destes, somente 64 dos pistoleiros e tão só 15 dos mandantes destes crimes foram condenados pelo judiciário. ${ }^{49}$ Somente dois dos 146 policiais responsáveis pelo massacre de 19 camponeses em 1996 em Eldorado dos Carajás foram condenados pela Justiça. Todos os outros foram formalmente absolvidos. Ainda mais, os dois oficiais condenados estão respondendo ao processo em plena liberdade.

Em meio a todos estes conflitos, setores importantes da elite política e a mídia brasileira têm freqüentemente retratado o MST como uma organização violenta e desordeira, liderada por fanáticos radicais. ${ }^{50}$ Algumas destas opiniões têm sido assimiladas pelos meios de comunicação e respeitados analistas ao redor do mundo. Por exemplo, em um artigo recente sobre movimentos populares contemporâneos na América Latina, o editor de Foreign Policy, um jornal de prestígio publicado pelo Carnegie Endowment for International Peace, descreveu o movimento sem-terra do Brasil como advogando "políticas lunáticas". 51

\footnotetext{
${ }^{49}$ Veja CPT (2004).

${ }^{50}$ Um bom exemplo deste tratamento pode ser encontrado na recorrente descrição do MST feita pela Revista Veja. Veja é a revista semanal de maior vendagem do Brasil. Artigos recentes sobre o movimento sem-terra incluem os seguintes títulos: "As Madraçais do MST", do dia 08 de setembro de 2004; "A Esquerda Delirante", capa da edição de 18 de junho de 2003; "A Bagunça Promovida pelo MST", de 03 de abril de 2003; "A Tática da Baderna", capa da edição de 10 de maio de 2000; "A Esquerda com Raiva", de 03 de junho de 1998. Os advogados do MST processaram a Veja pela sua edição de 10 de maio de 2001. Mais tarde naquele ano, a Justiça brasileira culpou a revista por difamar o movimento e seus líderes e ordenou a editora a compensar o MST por danos morais. Ver, Sociedade Interamericana de Imprensa (2001).

${ }^{51}$ Naím (2004).
} 
Mas, de todas as organizações de camponeses envolvidas em lutas pela terra no Brasil, o MST é certamente o mais disciplinado e orientado a atuar de forma nãoviolenta. Por falta de uma séria política nacional de reforma agrária, grupos camponeses têm sido deixados com poucas alternativas ao uso da força de sua mobilização e táticas de pressão. Assim, o radicalismo do MST deveria ser compreendido, principalmente, como uma reação às condições adversas que têm dificultado a implementação da reforma agrária no Brasil.

A reforma agrária não é uma "política de lunáticos." Quase todas as nações substancialmente desenvolvidas que têm conseguido níveis significativos de eqüidade social têm experimentado algum tipo de redistribuição de terras. Casos memoráveis disso são os dos países industrializados do leste asiático, tais como, Japão, Taiwan, Coréia do Sul e China. No Brasil de hoje, reforma agrária é um modo relativamente barato de geração de empregos. Em uma sociedade notadamente desigual como o Brasil, com altos níveis de desemprego estrutural e subemprego, a distribuição de terras poderia ajudar a prover empregos e promover condições para o avanço do desenvolvimento econômico. De fato, um amplo estudo sobre os assentamentos da reforma agrária, encomendado pelo governo brasileiro, indica que esta política tem ajudado a melhorar substancialmente as condições de vida dos assentados, ao tempo que tem estimulado o crescimento econômico em muitas áreas rurais. ${ }^{52}$

Pode-se encontrar muito poucos propulsores ideológicos da democracia liberal dentro do MST. Na realidade, os membros do MST são muito mais propensos a usar uma camiseta do Che Guevara do que uma impressa com a figura de John Locke, Thomas Jefferson ou Aléxis de Tocqueville. Dentro deste movimento, porém, podem-se encontrar alguns dos mais fervorosos praticantes da democracia entre os setores populares no Brasil.

Este ponto pode ser ilustrado com uma breve continuação da história da ocupação da Fazenda Annoni, em 1985, no Rio Grande do Sul, descrita no início deste trabalho. Por volta do início da década de 1990, 354 famílias foram assentadas na

\footnotetext{
52 Para os resultados desta importante investigação, realizado por uma competente equipe de pesquisadores, e patrocinada pelo Núcleo de Estudos Agrários e Desenvolvimento Rural (NEAD), do Ministério de Desenvolvimento Agrário, ver Leite et al. (2004)
} 
Annoni. O crescimento demográfico naquela área levou à criação de um novo município chamado Pontão, o qual celebrou suas primeiras eleições para prefeito em 1996. No Brasil, eleições municipais tendem a mobilizar políticos e eleitores em intensas disputas, devido ao poder substancial conferido às prefeituras.

A comunidade da Annoni era uma das maiores neste município majoritariamente rural. Por esta razão, o MST foi capaz de propor um dos seus assentados como candidato do PT, e vencer em uma eleição divida entre três forças políticas com quase $39 \%$ dos votos válidos. Isto representou mais uma vitória significativa para o MST, pois foi a primeira vez que um de seus membros foi eleito prefeito de seu município. A votação de 2000 para o governo local, todavia, envolveu uma apertada competição pela reeleição, uma vez que a oposição formou uma ampla coalizão contra a esquerda. O PT, entretanto, ganhou novamente com $56 \%$ dos votos válidos, graças aos esforços do MST junto aos assentados da Annoni. ${ }^{53}$ Por todas as aparências externas, tal feito pode ser interpretado como resultado de uma competição democrática convencional. A verdade, no entanto, é que a iniciativa eleitoral decisiva não foi tão delicada como pode se supor.

O clientelismo político é uma característica duradoura do processo eleitoral brasileiro. ${ }^{54}$ Durante as eleições, tais tradições freqüentemente levam à compra de votos, uma prática que afeta especialmente as camadas sociais mais pobres do país. Embora o Brasil tenha uma legislação forte para punir tal comportamento, ele não tem nenhum mecanismo eficaz para fazer respeitar estas leis. Nos meses que precederam a votação de 2000, cabos-eleitorais da coalizão anti-PT no Pontão, organizaram-se para comprar o apoio necessário para ganhar as eleições. Dias antes das eleições, eles foram para as estradas vicinais oferecendo pneus para carros, dinheiro e mantimentos em troca de votos. Mas os ativistas do PT contra-atacaram montando uma barreira a noite toda, vigiando as estradas com armas na mão para prevenir seus rivais de comprarem os votos de seus eleitores mais fracos. Uma noite, o grupo que bloqueava a estrada deu tiros de

\footnotetext{
${ }^{53}$ As eleições municipais de 2000 confirmaram a predominância do PT com 58 \% de vitória. Os dados da eleição citados aqui foram fornecidos por Manoel Caetano de Araújo do Núcleo de Pesquisa e Documentação da Política Rio-Grandense (NUPERGS), da Universidade Federal do Rio Grande do Sul (UFRGS).

${ }^{54}$ Para discussões válidas sobre o clientelismo brasileiro ver Mainwaring (1999) e Avelino (1994). O estudo clássico brasileiro sobre este assunto foi escrito por Leal (1993).
} 
aviso para assustar um veículo que se aproximava. Noutro dia, os militantes do PT fizeram a polícia parar um caminhão cheio de pneus. E, nesse meio tempo, eles conseguiram reter um segundo caminhão carregado com mantimentos. Assim, eles foram capazes de assegurar uma tensa vitória eleitoral em Pontão. ${ }^{55}$

As lições retiradas de tudo isto devem estar claras a esta altura. Dadas as cruas realidades da política brasileira e as condições cruéis sob as quais a reforma agrária deve ser implementada, não se pode esperar que a contribuição do MST para a democracia no Brasil seja nada menos do que forte, musculosa e áspera. Por virtude de nascimento e necessidade, a marca notável do MST tem sido a do "jogo duro".

\section{Bibliografia}

"ACÕES DO MST-RS, 1979-1996." [7-10-2003] Disponível em: http://empresa.portoweb.com.br/mstrs/acoes.

ADRIANCE, Madeleine R. Terra Prometida: As Comunidades Eclesiais de Base e os Conflitos Rurais. São Paulo: Edições Paulinas, 1996.

AMINZADE, Ronald R. and Doug McAdam. "Emotions and Contentious Politics," Silence and Voice in the Study of Contentious Politics, organizado por Ronald R, Aminzade, et al. Cambridge: Cambridge University Press, 2001.

AVELINO FILHO, George. "Clientelismo e Política no Brasil: Revisitando Velhos Problemas," Novos Estudos, 38 (March 1994), pp. 225-240.

BEOZZO, Pe. José Oscar. A Igreja do Brasil: De João XXIII a João Paulo II, de Medellín a Santo Domingo. Petrópolis: Vozes, 1994.

BERGER, Christa. Campos em Confronto: A Terra e o Texto. Porto Alegre: Editora da Universidade/UFRGS, 1998.

\footnotetext{
${ }^{55}$ Este relato foi reunido durante uma visita de campo a Pontão e municipalidades vizinhas pouco depois das eleições municipais de 2000. Problemas com compra de votos ou tentativas de fazê-lo foram reportadas na maioria dos distritos próximos. Como tal, candidatos progressistas tiveram sucesso somente onde eles foram capazes de aplicar uma tática similar de pulso-forte para impedir as tentativas de compra de votos de seus adversários.
} 
BOBO, Kimberly A, Jackie Kendall, and Steve Max, editors. Organizing For Social Change: A Manual for Activists in the 1990s. Santa Ana: Seven Locks Press, 1996.

BRANCH, Taylor. Parting the Waters: America in the King Years, 1954-63. New York: Simon and Schuster, 1988.

BRANFORD, Sue and Rocha, Jan. Cutting the Wire: The Story of the Landless Movement in Brazil. London: Latin American Bureau, 2002.

CALDART, Roseli Salete. Pedagogia do Movimento Sem Terra: Escola é Mais do que Escola, 2 ed, Petrópolis: Vozes, 2000.

CARTER, Miguel, editor. Challenging Social Inequality: The Landless Rural Workers' Movement (MST) and Agrarian Reform in Brazil. Manuscrito Inédito, 2005a.

CARTER, Miguel. For Land, Love, and Justice: The Origins of Brazil's Landless Workers Movement. Manuscrito Inédito, $2005 \mathrm{~b}$.

CARTER, Miguel. “The Origins of Brazil's Landless Rural Workers' Movement (MST): The Natalino Episode in Rio Grande do Sul (1981-84). A Case of Ideal Interest Mobilization.” Working Paper Number CBS-43-03, Centre for Brazilian Studies, University of Oxford, 2003.

CARVALHO, Horácio Martins de. "MST Settlements: Achievements, Obstacles and Prospects," Challenging Social Inequality: The Landless Rural Workers' Movement (MST) and Agrarian Reform in Brazil, organizado por Miguel Carter. Manuscrito Inédito, 2005.

CARVALHO, Horácio Martins de. "A Emancipação do Movimento no Movimento de Emancipação Social Continuada (Resposta a Zander Navarro)." Produzir para Viver: Os Caminhos da Produção Não Capitalista, org. Boaventura de Sousa Santos. São Paulo: Civilização Brasileira, 2002.

CHAVES, Christine de Alencar. A Marcha Nacional dos Sem-Terra: Um Estudo Sobre a Fabricação do Social. Rio de Janeiro: Relume Dumará, 2000.

COLBURN, Forrest D, editor. Everyday Forms of Peasant Resistance. Armonk: M.E. Sharpe, 1989

COMISSÃO PASTORAL Da TERRA (CPT). “Assassinatos e Julgamentos 1985-2003.” Setor de Documentação. Relatório não publicado, 2004. 
COMISSÃO PASTORAL DA TERRA (CPT). Conflitos no Campo Brasil 2003. Goiânia: CPT, 2004.

COMPARATO, Bruno Konder. A Ação Política do MST. São Paulo: Editora Expressão Popular, 2003.

DALlAGNOL, Wilson. As Romarias da Terra no Rio Grande do Sul: Um Povo a Caminho da "Terra Prometida." Canoas: Gráfica La Salle, 2002.

DELGADO, Guilherme Costa. "The Agrarian Question in Brazil, 1950-2003," Challenging Social Inequality: The Landless Rural Workers' Movement (MST) and Agrarian Reform in Brazil, organizado por Miguel Carter. Manuscrito Inédito, 2005.

DELLA CAVA, Ralph. 'The 'People's Church,' the Vatican and the Abertura” In Democratizing Brazil, organizado por Alfred Stepan. New York: Oxford University Press, 1989.

DOS SANTOS, Andrea Paula, Suzana Lopes Salgado Ribeiro and José Carlos Sebe Bom Meihy. Vozes da Marcha pela Terra. São Paulo: Edições Loyola, 1998.

FAORO, Raymundo. Os Donos do Poder: Formação do Patronato Político Brasileiro, Volumes 1 and 2 (Rio de Janeiro: Editora Globo, 1957)

FERNANDES, Bernardo Mançano. "The Formation and Territorialization of the MST in Brazil," Challenging Social Inequality: The Rural Workers' Landless Movement (MST) and Agrarian Reform in Brazil, organizado por Miguel Carter. Manuscrito Inédito, 2004.

FERNANDES, Bernardo Mançano. A Formação do MST no Brasil. Petrópolis: Vozes, 2000.

FLÁVIO DE ALMEIDA, Lúcio and Félix Ruiz Sánchez. "The Landless Workers' Movement and Social Struggles Against Neoliberalism," translated by Laurence Hallewell, Latin American Perspectives. 114, $27: 5$ (September 2000), pp.11-32.

FORMAN, Shepard. The Brazilian Peasantry. New York: Columbia University Press. 1975.

FOX, Jonathan. "The Difficult Transition from Clientelism to Citizenship: Lessons from Mexico.” World Politics 46: 2 (January, 1994), pp. 151-184. 
GOODWIN, Jeff, James M. Jasper, and Francesca Poletta, editors. Passionate Politics: Emotions and Social Movements. Chicago: The University of Chicago Press, 2001.

GRAZIANO, Xico. O Carma da Terra. São Paulo: A Girafa, 2004.

GUIMARÃES, Alberto Passos. Quatro Séculos de Latifúndio, 6 ed. Rio de Janeiro: Editora Paz e Terra, 1989.

GUIMARÃES, Alberto Passos. A Crise Agrária. Rio de Janeiro: Paz e Terra, 1982.

HAMMOND, John L. "Law and Disorder: The Brazilian Landless Farmworkers' Movement." Bulletin of Latin American Research. 18:4 (1999), pp. 469-489.

HIRSCHMAN, Albert O. Shifting Involvements: Private Interest and Public Action. Princeton: Princeton University Press, 1982.

INSTITUTO BRASILEIRO DE GEOGRAFIA E ESTATÍSTICA (IBGE). Censo Agropecuário 1996. Volume 1. Rio de Janeiro: IBGE, 1996.

INSTITUTO NACIONAL DE COLONIZAÇÃO E REFORMA AGRÁRIA - Rio Grande do Sul (INCRA-RS). "Invasões de Terra no Rio Grande do Sul - Peíodo: Maio de 1978 à 10 de Março 2003." Unpublished Document, 2003.

INSTITUTO DE PESQUISA ECONOMICA APLICADA, IPEA (2005). Radar Social. Brasília: IPEA.

KANE, Liam. Popular Education and Social Change in Latin America. London: Latin America Bureau, 2001.

KOLLING, Edgar Jorge, Paulo Ricardo Cerioli, e Roseli Salete Caldart (orgs.). Educação do Campo: Identidade e Políticas Públicas: Por uma Educação do Campo. Coleção Por Uma Educação do Campo No. 4. Brasília: Articulação Nacional Por Uma Educação do Campo, 2002.

LE BRETON, Binka. Todos Sabiam: A Morte Anunciada do Padre Josimo. São Paulo: CPT / Edições Loyola, 2000.

LEAL, Victor Nunes. Coronelismo, Enxada e Voto, 6 ed. São Paulo: Editora AlfaOmega, 1993 [1949].

LEITE, Sergio, et al., (orgs). Impactos dos Assentamentos: Um Estudo sobre o Meio Rural Brasileiro. Brasília : Núcleo de Estudos Agrários e Desenvolvimento Rural (NEAD), 2004. 
MAINWARING, Scott P. Rethinking Party Systems in the Third Wave of Democratization: The Case of Brazil. Stanford: Stanford University Press, 1999.

MAINWARRING, Scott. The Catholic Church and Politics in Brazil, 1916-1985. Stanford: Stanford University Press, 1986.

MARKOFF, John. Waves of Democracy: Social Movements and Political Change. Thousand Oaks: Pine Forge Press, 1996.

MARSHALL, T. H. "Citizenship and Social Class." Citizenship and Social Class, organizado por Tom Bottomore. London: Pluto Press, 1992.

MARTINS, José de Souza. O Sujeito oculto: ordem e transgressão na reforma agrária. Porto Alegre: Editora da Universidade/UFRGS, 2003.

MARTINS, José de Souza. Reforma Agrária: O Impossível Diálogo. São Paulo: Editora da Universidade de São Paulo, 2000.

MARTINS, José de Souza. “A Questão Agrária Brasileira e o Papel do MST," A Reforma Agrária e a Luta do MST, editado por João Pedro Stédile. Petrópolis: Vozes, 1997.

MARTINS, José de Souza. O Poder do Atraso: Ensaios de Sociologia da História Lenta. São Paulo: Editora HUCITEC, 1994.

MARTINS, José de Souza. Expropriação e Violência: A Questão Política no Campo, 3 ed. revisada. São Paulo: HUCITEC, 1991

MARTINS, José de Souza. Os Camponeses e a Política no Brasil. 4 ed. Petrópolis: Vozes, 1990.

MARTINS, Mônica Dias. "The MST Challenge to Neoliberalism." Latin American Perspectives. 27:5 (September 2000), pp. 33-45.

MARTINS, José Pedro S. "Brasil: Cinco Siglos Sin Tierra," Noticias Aliadas. [12-022005] Disponível em: http://www.lapress.org/article.asp?lanCode=2\&artCode=1255.

MEDEIROS, Leonilde Sérvolo de. História dos Movimentos Sociais no Campo. Rio de Janeiro: FASE, 1989.

MÉNDEZ, Juan E. Guillermo O’Donnell, and Paulo Sergio Pinheiro, (editors). The (Un)Rule of Law and the Underprivileged in Latin America. Notre Dame: Notre Dame University Press. 
MESZAROS, George. "The MST and the Rule of Law in Brazil," Challenging Social Inequality: The MST and Agrarian Reform in Brazil, organizado por Miguel Carter. Manuscrito Inédito, 2005

MESZAROS, George. "No Ordinary Revolution: Brazil's Landless Workers' Movement." Race \& Class. 42:2 (2000), pp.1-18.

MESZAROS, George. "Taking the Land into their Hands: The Landless Workers' Movement and the Brazilian State." Journal of Law and Society. 27:4 (December 2000), pp.517-41.

MINISTÉRIO DE DESENVOLVIMENTO AGRÁRIO (MDA); Instituto Nacional de Colonização e Reforma Agrária (INCRA); Superintendência Nacional de Desenvolvimento Agrário (SND). "Projetos de Reforma Agrária Conforme Fases de Implementação: Período da Criação do Projeto - 01/01/1900 até 24/07/2003." Unpublished Document, July 2003.

MORISSAWA, Mitsue. A História da Luta pela Terra e o MST. São Paulo: Expressão Popular, 2001.

MOVIMENTO DOS TRABALHADORES RURAIS SEM TERRA (MST) (2005), "Setor de Direitos Humanos." Disponível em: http://www.mst.org.br/setores/dhumanos/dhumanos.html

MOVIMENTO DOS TRABALHADORES RURAIS SEM TERRA (MST) (2004a). "Quem Somos, 1984-2004: 20 Anos de Lutas, Conquistas, e Dignidade!" [2-102004] Disponível em: http://www.mst.org.br/historico/história.htm.

MOVIMENTO DOS TRABALHADORES RURAIS SEM TERRA (MST) (2004b). “O MST e a Educação," [2-10-2004] Diponível em: http://www.mst.org.br/setores/educacao/educar.html.

MOVIMENTO DOS TRABALHADORES RURAIS SEM TERRA (MST), "MST em Dados.” São Paulo: ANCA, 2003.

MOVIMENTO DOS TRABALHADORES RURAIS SEM TERRA - Rio Grande do Sul (MST-RS),

NAÍM, Moisés. "From Normalcy to Lunacy." Foreign Policy, 141 (March/April 2004). 
NAVARRO, Zander. "Mobilização sem Emancipação - As Lutas Sociais dos Sem Terra no Brasil.” Produzir para Viver: Os Caminhos da Produção Não Capitalista, org. Boaventura de Sousa Santos. São Paulo: Civilização Brasileira, 2002a.

NAVARRO, Zander. "O MST e a Canonização da Ação Coletiva (Reposta a Horácio Martins Carvalho)." Produzir para Viver: Os Caminhos da Produção Não Capitalista, org Boaventura de Sousa Santos. São Paulo: Civilização Brasileira, $2002 b$.

NAVARRO, Zander. "Democracia, Cidadania e Representação: Os Movimentos Sociais Rurais no Estado do Rio Grande do Sul," Política, Protesto e Cidadania no Campo: As Lutas Sociais dos Colonos e Trabalhadores Rurais do Rio Grande do Sul, org. Zander

NAVARRO. Porto Alegre: Editora da Universidade Federal do Rio Grande do Sul, 1996.

ONDETTI, Gabriel. "Revolution or Palliative? Assessing the Cardoso Era Reform," Prepared Delivered at the 2004 Meeting of the Latin American Studies Association, Las Vegas, Nevada, October 7-9.

ONDETTI, Gabriel. "Opportunities, Ideas and Actions: The Brazilian Landless Movement, 1979-2001." Ph.D. Thesis, University of North Carolina at Chapel Hill, 2002.

PAIVA, Vanilda, editor. Igreja e Questão Agrária. São Paulo: Loyola, 1985.

PAYNE, Leigh A. Uncivil Movements: The Armed Right Wing and Democracy in Latin America. Baltimore: The Johns Hopkins University Press, 2000.

PETRAS, James and Henry Veltmeyer. "Are Latin American Peasant Movements Still a Force for Change? Some New Paradigms Revisited," The Journal of Peasant Studies. 28:2 (January 2001), pp.83-118.

POLETTO, Ivo. "Churches, the Pastoral Land Commission and the Mobilization for Agrarian Reform," Challenging Social Inequality: The Landless Rural Worker's Movement (MST) and Agrarian Reform in Brazil, organizado por Miguel Carter. Manuscrito Inédito, 2005.

POletTo, Ivo e Antônio Canuto, (orgs.). Nas Pegadas do Povo da Terra: 25 Anos da Comissão Pastoral da Terra. São Paulo: Edições Loyola, 2002. 
ROSA, Marcelo. "The MST and Contemporary Social Movements," Challenging Social Inequality: The Landless Rural Worker's Movement (MST) and Agrarian Reform in Brazil, organizado por Miguel Carter. Manuscrito Inédito, 2005.

SARTORI, Giovanni. The Theory of Democracy Revisited (Chatham: Chatham House Publishers, 1987)

SCHMINK, Marianne and Charles H. Wood, Contested Frontiers in Amazonia (New York: Columbia University Press, 1992);

SCHMITTER, Philippe C. "Still the Century of Corporatism?" Review of Politics, 36 (January 1974), pp. 86-131.

SCOLESE, Eduardo. "Invasões de terra têm aumento de 115\% neste ano," Folha de São Paulo, 23 June 2004. [2-10-2004] Disponível em: http://www1.folha.uol.com.br/folha/brasil/ult96u61889.shtml.

SCOTT, James C. Weapons of the Weak: Everyday Forms of Peasant Resistance. New Haven: Yale University Press, 1985.

SCOTT, James C. Domination and the Arts of Resistance: Hidden Transcripts. New Haven: Yale University Press, 1990.

SILVA, Lígia Osori. Terras Devolutas e Latifúndio: Efeitos da Lei de 1850. Campinas: Editora da UNICAMP, 1996.

SMULOVITZ, Catalina and Enrique Peruzzotti. "Societal Accountability in Latin America." Journal of Democracy, 11:4 (October 2000), pp. 147-158.

SNYDER, Richard and David J. Samuels, "Legislative Malapportionment in Latin America: Historical and Comparative Perspectives," Federalism and Democracy in Latin America, organizado por Edward L. Gibson. Baltimore: The Johns Hopkins University Press, 2004, pp. 131-172.

SOCIEDADE INTERAMERICANA DE IMPRENSA, "Brasil - Relatórios País-porPaís." 57 Assembléia da SIP em Washington, D.C, 12 a 16 de outubro de 2001 [210-2004] Disponível em: http://www.sipiapa.org/portugues/pulications/informe_brasil2002.cfm.

SPAROVEK, Gerd. A Qualidade dos Assentamentos da Reforma Agrária Brasileira. São Paulo: Páginas \& Letras Editora e Gráfica, 2003. 
STÉDILE, João Pedro. A Questão Agrária no Brasil. 7 ed. São Paulo: Editora Atual, 1999.

STÉDILE, João Pedro (org.). A Reforma Agrária e a Luta do MST. Petrópolis: Vozes, 1997.

STÉDILE, João Pedro e Bernardo Mançano Fernandes. Brava Gente: A Trajetória do MST e a Luta pela Terra no Brasil. São Paulo: Editora da Fundação Perseu Abramo, 1999.

STÉDILE, João Pedro e Frei Sergio Görgen. A Luta Pela Terra no Brasil. São Paulo: Editora Página Aberta, 1993.

STEPAN, Alfred. Arguing Comparative Politics. Oxford: Oxford University Press, 2001.

TILLy, Charles. Social Movements, 1768-2004. Boulder and London: Paradigm Publishers, 2004.

TILLY, Charles. Stories, Identities, Political Change. Oxford: Rowman \& Littlefield, 2002.

TILLY, Charles. "Speaking Your Mind without Elections, Surveys, or Social Movements," Public Opinion Quarterly, 47:4 (Winter 1983), pp. 461-78.

TILLY, Charles. "Repertoires of Contention in America and Britain," The Dynamics of Social Movements, organizado por Mayer N. Zald and John D. McCarthy. Cambridge, Mass.: Winthrop, 1979.

VELTMEYER, Henry and James Petras. "The Social Dynamics of Brazil's Rural Landless Workers' Movement: Ten Hypotheses on Successful Leadership." Canadian Review of Sociology and Anthropology. 39:1 (2002).

WEBER, Max. From Max Weber: Essays in Sociology, organizado por H.H. Gerth and C. Wright Mills. New York: Oxford University Press, 1958.

WEBER, Max. Economy and Society, organizado por Guenther Roth and Claus Wittich. Berkeley: University of California, 1978.

WHITEHEAD, Laurence. Democratization: Theory and Experience. Oxford: Oxford University Press, 2002

WRIGHT, Angus and Wendy Wolford. To Inherit the Earth: The Landless Movement and the Struggle for a New Brazil. Oakland: Food First Books, 2003. 
Tradução: Imario Vieira

Revisão: Eduardo Castro e Marta Inez Medeiros Marques

Revisão Final: Miguel Carter 